\title{
Prototype of a web and mobile application for inventory management of a parts store using QR code
}

\section{Prototipo de aplicación web y móvil para la gestión de inventario de una refaccionaria utilizando código $\mathbf{Q R}$}

MORALES-HERNÁNDEZ, Maricela †*, MORALES-JIMÉNEZ, Itzel, OSORIO-HERNÁNDEZ, Luis Eduardo and DIAZ-SARMIENTO, Bibiana

Tecnológico Nacional de México/Instituto Tencológico de Oaxaca. Avenida Ing. Víctor Bravo Ahuja No. 125 Esquina Calzada Tecnológico, C.P. 68030; Oaxaca de Juárez, Oaxaca.

ID $1^{\text {st }}$ Author: Maricela, Morales-Hernández / ORC ID: 0000-0002-3521-2041, CVU CONACYT ID: 731036

ID $1{ }^{\text {st }}$ Co-author: Itzel, Morales-Jiménez / ORC ID: 0000-0002-5582-5507, CVU CONACYT ID: 1146986

ID $2^{\text {nd }}$ Co-author: Luis Eduardo, Osorio-Hernández / ORC ID: 0000-0003-3879-1146, CVU CONACYT ID: 1146936

ID $3^{\text {rd }}$ Co-author: Bibiana, Díaz-Sarmiento / ORC ID: 0000-0003-4350-6311, CVU CONACYT ID: 820776

DOI: $10.35429 / J C S I .2021 .19 .7 .9 .20$

Received July 18, 2021; Accepted October 30, 2021

\begin{abstract}
Abtract
Micro-companies have been a sector with a great disadvantage in recent months due to the global health problem; hence, the interest in offering a technological tool that allows them to improve customer service. The objective of this article is to present a project, which it was developed for an automotive parts store in Oaxaca city. The idea of introducing technologies such as the use of web applications integrating the QR code to facilitate inventory management will allow these micro-companies to offer an improved service. The contribution of this project is that it can be adapted to different types of microcompanies that require technological tools that support them in their survival in an increasingly competitive market. The prototype is developed with the agile Extreme Programming (XP) methodology, and the tools used are Laravel and Boostrap frameworks for the web application and for the mobile application: Android Studio and Material Design.
\end{abstract}

QR code, Web application, Mobile app

\begin{abstract}
Resumen
Las microempresas han sido un sector con gran desventaja en los últimos meses debido al problema de salud a nivel mundial, de allí, el interés de ofrecer una herramienta tecnológica que les permita mejorar la atención a sus clientes. El objetivo del presente artículo, es presentar un proyecto desarrollado para una refaccionaria automotriz en la ciudad de Oaxaca de Juárez, Oaxaca. La idea de introducir tecnologías como el uso de aplicaciones web integrando el código QR para facilitar la gestión de los inventarios, permite a estas microempresas, ofrecer un servicio mejorado. La contribución del presente proyecto es que, éste puede adaptarse a diferentes tipos de microempresas que requieran de herramientas tecnológicas que les apoyen en su supervivencia en un mercado cada día más competitivo. El prototipo es desarrollado con la metodología ágil Extreme Programming (XP), y las herramientas utilizadas son frameworks Laravel y Boostrap para la aplicación web y para la aplicación móvil Android Studio y Material Design.
\end{abstract}

Código QR, Aplicación web, Aplicación móvil

Citation: MORALES-HERNÁNDEZ, Maricela, MORALES-JIMÉNEZ, Itzel, OSORIO-HERNÁNDEZ, Luis Eduardo and DIAZ-SARMIENTO, Bibiana. Prototype of a web and mobile application for inventory management of a parts store using QR code. Journal of Computational Systems and ICTs. 2021.7-19: 9-20

\footnotetext{
*Correspondence to Author (e-mail: maricela.morales@itoaxaca.edu.mx)
}

$\dagger$ Researcher contributing as first author. 


\section{Introduction}

Currently web applications have grown rapidly, especially in recent months in which new business models have emerged; and many of them include a mobile application as a plus value. Web applications have become popular due to the practicality of the web browser as a light client, they can be run on any operating system, and it is not necessary to install or distribute software to users (Ferrer, 2015). On the other hand, the popularity of mobile applications is increasing with the use of smart devices and the applications created for them, have become stable over time. (David, 2021). In addition, users of mobile applications increasingly require real-time information that it can be consulted from their mobile devices for quick decision-making in their companies, no matter how small they were.

There are mobile and prepackaged solutions on the market that do not require code, up to fully customized solutions and development platforms integrated into mobile devices (Redhat, 2021); however, small businesses sometimes require ad hoc solutions that do not expense many resources on their devices.

The aim of this article is to show a technological solution for micro-companies in the automotive parts sales branch, a solution that contributes to their permanence in the market, given the health conditions that are experienced in the world. Since small businesses in all cities have been hit by the restrictions imposed by the federal, state and municipal governments, and have not achieved the expected sales from the massive lockdown.

This web application in conjunction with the mobile application gives "Refaccionaria R" the possibility of using technology in its favor, applying QR code in the early identification of its parts within its warehouse. The QR code is a type of barcode that is easily readable with digital devices such as smartphones and stores information in a series of pixels contained in a square (Business Insider México, 2021). The acronym QR comes from the English phrase quick response, since the creator aspired for the code to allow its content to be read at high speed (Velasco, 2014).
The article contains next sections: introduction, problem statement, developing methodology, development, results, future work, acknowledgments, conclusions and references. In the first section, the problem that originated the proposal of the developed prototype is presented. In the second section the methodology applied for the development of the software is explained, the development section shows the three iterations that were worked on to obtain the functional prototype of the web and mobile applications; the results section shows the prototype with its functionalities. Subsequently, it was added a section where the next steps of this project are enunciated, that is, the possible future developments. There is a section of thankfulnesses, where the determined support of those who made the achievement of the project aims possible is recognized. Finally, the conclusions reached are explained, and the references consulted are listed.

\section{Problem Statement}

Micro-enterprises dedicated to the buy and sale of automotive parts that operate in the municipality of Oaxaca de Juárez, in the state of Oaxaca, have different problems with their inventories, such as

a. Lack of control and location of parts in the warehouse.

b. Supplier contacts are easily lost since records are carried out manually.

c. At a certain moment, the real number of automotive parts they manage and their existence in the warehouse is unknown.

d. Loss of pieces from a low monetary value to high values that impact a financial loss.

e. The organization of the pieces does not follow a standard, since identification codes of the pieces are not handled.

f. The classification of parts is ambiguous, leading to errors when supplying orders to customers.

g. Monetary losses on products that are not sold in the appropriate time and remain indefinitely in the warehouse.

The above information was obtained from a series of interviews with the manager of an automotive parts microenterprise, which for confidentiality reasons we will call "Refaccionaria R". 


\section{Developing methodology}

Software quality is an issue that has become more important in recent times and to which greater attention should be paid, not only from a research point of view, but also from a business point of view (Calero, Moraga \& Piattini, 2010), a point of view that is very relevant when using an agile user-oriented methodology such as extreme programming.

For the development of this work, the agile Extreme Programming (XP) methodology is used, since according to Molinero (2018), XP teams carry out almost all software development activities simultaneously and organize software development in iterations of a short time (regularly a week) and this allows mistakes and successes to be clearly associated with their causes.

XP was designed for small and mediumsized projects, focused on customer needs. In addition, it describes in detail the development of the software such as programming language, refactoring, unit tests, etc. (Laínez, 2015).

In this work, the Xp phases stated by Molinero (2018) are considered for the iterations that are defined in the development of a functional prototype:

$\begin{array}{ll}\text { 1. } & \text { Planning } \\ \text { 2. } & \text { Analysis } \\ \text { 3. } & \text { Design and coding } \\ \text { 4. } & \text { Tests } \\ \text { 5. } & \text { Deployment }\end{array}$
iteration.

Phases are performed in each planned

The tools used in the prototype programming are, first, laravel, which is an easyto-program framework, since it contains the same tools as other web frameworks such as "Ruby on Rails" (Laravel, 2021). Second, Android Studio was used for the mobile application, which according to Android (2021) is the official integrated development environment (IDE) for developing Android apps and is based on IntelliJ IDEA which according to its official page is an integrated development environment (IDE) for JVM (Java Virtual Machine) languages designed to maximize developer productivity (IntelliJ IDEA, 2021).

\section{Development}

As already indicated in the previous section, the agile XP methodology was applied for the development of the prototype. The first thing that was done was to work with the identification of the functional requirements of the prototype. For this, the processes that the company carries out in its activities related to the inventory of automotive spare parts are identified. As an example, some of the identified processes are shown.

In Figure 1, the spare parts ordering process is presented, it can be seen that the warehouse manager generates a tentative list of spare parts to buy. Subsequently, he compares the prices of the same with different suppliers, with that information he generates a definitive list of the spare parts that are required. Next, the general manager of the company reviews the list and, if necessary, makes changes that he considers pertinent, once he analyzes the list and agrees with it, he authorizes the sending of the order list to his suppliers, the process ends when the supplier receives the order.

Figure 2 represents the process of receiving and storing spare parts, which begins when the supplier provide a previously made order, the warehouse manager receives the orders, signs receipt, and verifies what is received according to the invoice issued by the supplier. If the quantities coincide, and the product is purchased for the first time, it is assigned a location in the warehouse, if it is not a new product; it is accommodated according to the classification already established. The price of the product and its existence are updated, the invoice is delivered to the manager, and he receives it and concludes this process.

On the other hand, if the quantities or spare parts do not match, the manager notifies the supplier and if required, the supplier adjusts the total amount of the invoice, and if necessary applies the corresponding discount. Finally, the supplier generates the invoice again, sending it to the manager of the parts store, concluding the process. 


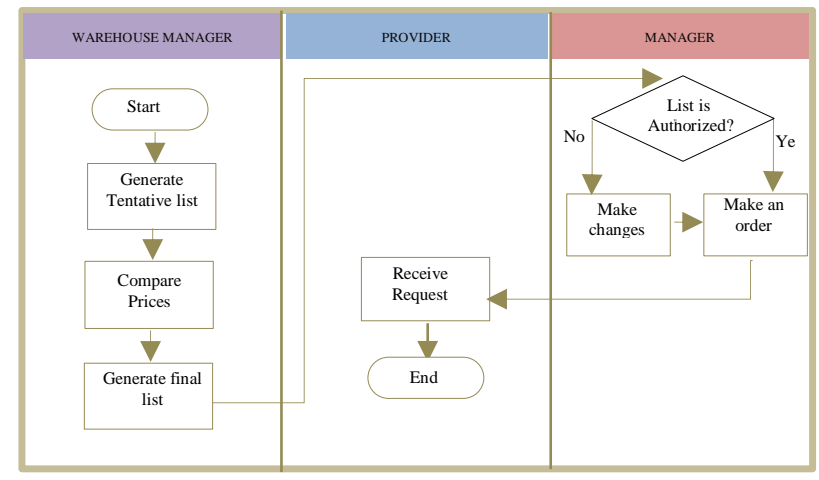

Figure 1 Spare parts ordering process Source: Own Work

In Figure 3, the process of payment to suppliers is observed, which begins when in which the manager determines the payment modality. If this is made on credit, the manager records in his control agenda the deadline for payment. If the payment is still within the allowed days, the manager performs it in a normal way, again registers the pay method in his control schedule and the process ends when the provider receives such payment. If it is exceeded the days allowed to settle it, the manager must do it with an extra charge.

In figure 4 , the cash sale process is detailed, it begins when a customer arrives at the $\mathrm{R}$, and requests a product, and the warehouse manager looks for the product. If it is not in your inventory, notify the employee to inform the customer, thus ending the process. On the other hand, if the product is in the warehouse, it is delivered to the employee, who asks the customer for the payment method. If it is in cash, the payment is made and the note is generated to deliver it with the product, ending the process. If the sale is on credit, the credit sale process is carried out, described in figure 5 .

In figure 5 you can see the credit sale process, this begins with the verification of the client's registration in the authorized clients' agenda. If not authorized, the employee goes to the general manager to authorize the search. If this does not authorize it, the client is notified and the process finishes. On the other hand, if the manager authorizes the customer to register, an account is generated to add the requested product to it; his or her remittance note is made at the employee for the customer. This process ends when the customer receives their delivery note and product.
Similarly, the other internal processes of the company that have a direct impact on inventory management were reviewed, which is one of the problems that leads to monetary losses, as well as customer service.

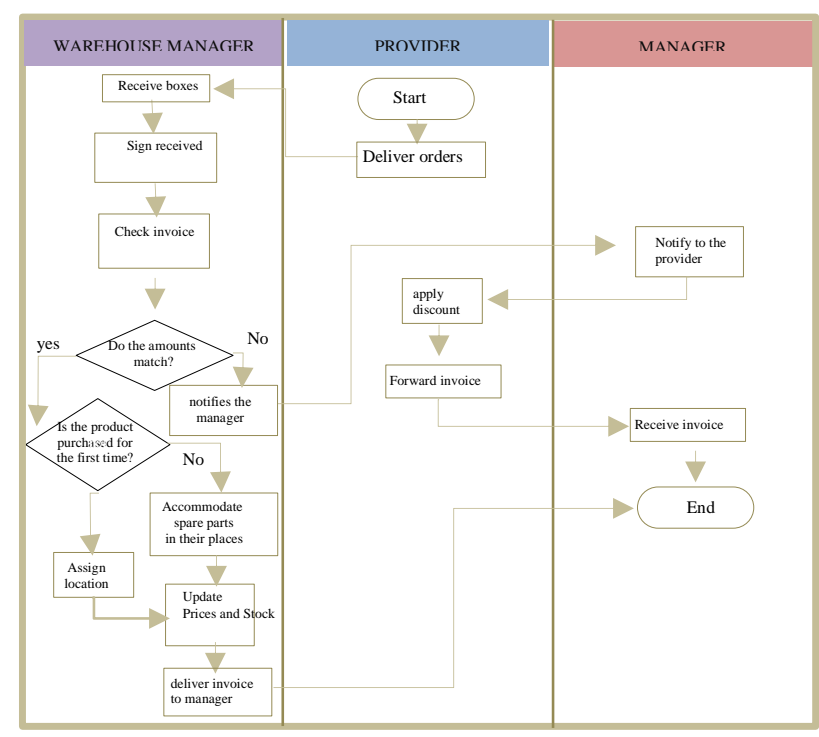

Figure 2 The process of receiving and storing spare parts. Source: Own Work

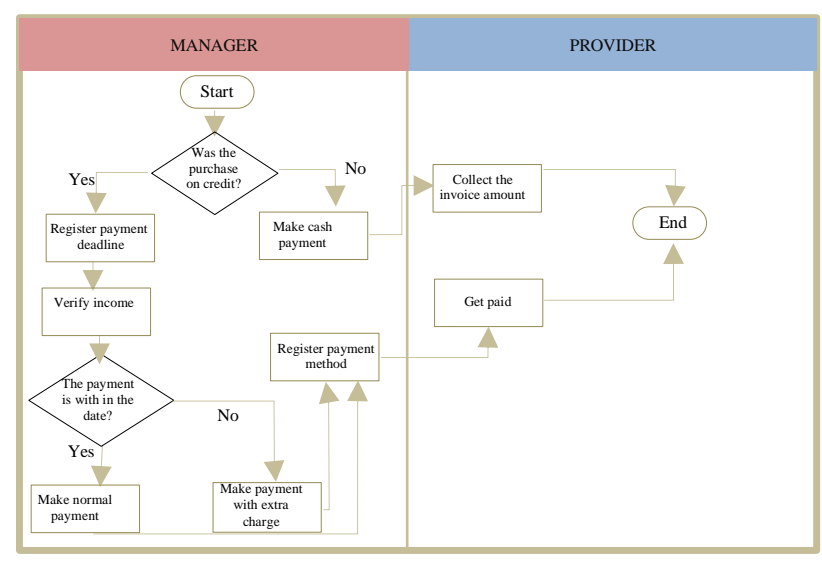

Figure 3 Supplier payment process Source: Own Work

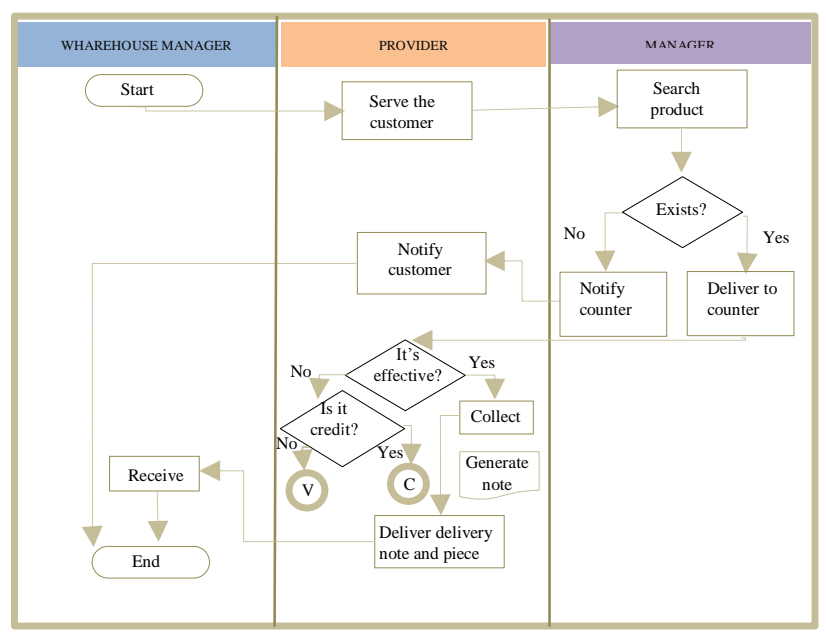

Figure 4 Cash sale process Source: Own Work. 


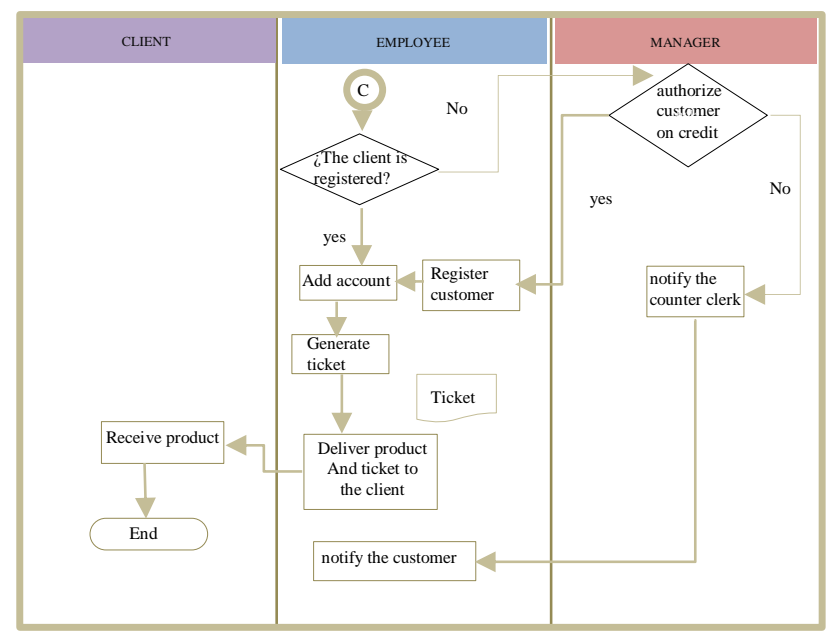

Figure 5 Credit sale process

Source: Own Work

Once the company's processes have been analyzed, a set of requirements is determined, which are presented in table 1.

\begin{tabular}{|l|l|}
\hline No. & \multicolumn{1}{|c|}{ Requirement } \\
\hline 1 & Management of web system users \\
\hline 2 & Customer management of the auto parts store \\
\hline 3 & Cash and credit sales management \\
\hline 4 & Supliers management \\
\hline 5 & Management of cash and credit sales \\
\hline 6 & Orders management \\
\hline 7 & Inventory management \\
\hline 8 & Management of vouchers given to customers \\
\hline 9 & Returns management \\
\hline 10 & $\begin{array}{l}\text { Various reports according to the needs of the } \\
\text { company }\end{array}$ \\
\hline 11 & Order management from the mobile application \\
\hline 12 & $\begin{array}{l}\text { Inventory management from the mobile } \\
\text { application }\end{array}$ \\
\hline 13 & QR code reading from the mobile application \\
\hline
\end{tabular}

Table 1 Functional requirements of the web system and mobile application

Source: Own Work

With the above information, the user stories were created, generating the master list of user stories, as shown in table 2.

\begin{tabular}{|c|c|c|c|}
\hline$\#$ & Title & $\begin{array}{l}\text { Assigned } \\
\text { iteration }\end{array}$ & $\begin{array}{c}\text { Estimated } \\
\text { points }\end{array}$ \\
\hline 1 & Sale of spare parts for cash & 2 & 3 \\
\hline 2 & Sales of spare parts on credit & 2 & 2 \\
\hline 3 & Parts register & 1 & 2 \\
\hline 4 & Clients register & 1 & 2 \\
\hline 5 & Supliers register & 1 & 2 \\
\hline 6 & Employs register & 1 & 2 \\
\hline 7 & Return of spare parts & 3 & 3 \\
\hline 8 & Generation of vouchers & 3 & 1 \\
\hline 9 & Charge with vouchers & 3 & 1 \\
\hline 10 & Register credit sales & 3 & 2 \\
\hline 11 & Preliminary list of spare parts & 2 & 3 \\
\hline 12 & Make order to suppliers & 2 & 3 \\
\hline 13 & Register cash purchases & 2 & 3 \\
\hline 14 & Register credit purchases & 2 & 2 \\
\hline 15 & Register sales & 2 & 2 \\
\hline 16 & Physical search for spare parts & 3 & 2 \\
\hline 17 & Register payments to suppliers & 3 & 2 \\
\hline
\end{tabular}

\begin{tabular}{|l|l|l|l|}
\hline 18 & Cancel orders & 2 & 1 \\
\hline 19 & Parts report & 3 & 1 \\
\hline 20 & Defective parts report & 3 & 1 \\
\hline 21 & Clients and suppliers report & 3 & 1 \\
\hline 22 & Sales report & 3 & 1 \\
\hline 23 & Purchases report & 3 & 1 \\
\hline 24 & Orders report & 3 & 1 \\
\hline 25 & Shelves catalog (QR Code) & 3 & 2 \\
\hline 26 & Quick information & 3 & 3 \\
\hline \multicolumn{2}{|l|}{ Total estimated points } & 46 \\
\hline
\end{tabular}

Table 2 User Stories Master List Source: Own Work

To solve the user stories, they were grouped into three iterations; these can be seen in Table 3.

\begin{tabular}{|l|l|l|}
\hline $\begin{array}{l}\text { Iteration } \\
\text { number }\end{array}$ & \multicolumn{1}{c|}{$\begin{array}{c}\text { Iteration } \\
\text { name }\end{array}$} & \multicolumn{1}{c|}{$\begin{array}{c}\text { Solved user stories } \\
\text { acording with table 2 }\end{array}$} \\
\hline 1 & Inventory & $3,4,5,6$ \\
\hline 2 & $\begin{array}{l}\text { Purchases, } \\
\text { orders and } \\
\text { cash sales }\end{array}$ & $1,2,11,12,13,14,15,17,18$ \\
\hline 3 & $\begin{array}{l}\text { Returns, } \\
\text { vouchers and } \\
\text { reports }\end{array}$ & $7,8,9,10,16,18,19,20,21$, \\
$22,23,24,25,26$
\end{tabular}

Table 3. Iteration planning

Source: Own Work

The following paragraphs explain what is done in each of the 4 iterations.

\section{Iteration 1. Inventory}

Planning: According to the planning of the master list set out in Table 3, the user stories with the highest value and average ease were taken into account, providing a solution to the inventory process, considered this as the basis of the prototype.

Analysis: Here the sequence diagrams were used, through which the requirements of the web application were obtained, taking into account all the actors involved in the inventory process. As an example some of the sequence diagrams made are shown.

Figure 6 shows an example of a sequence diagram for inventory. In a similar way, other diagrams were elaborated that supported the analysis phase of this iteration. 


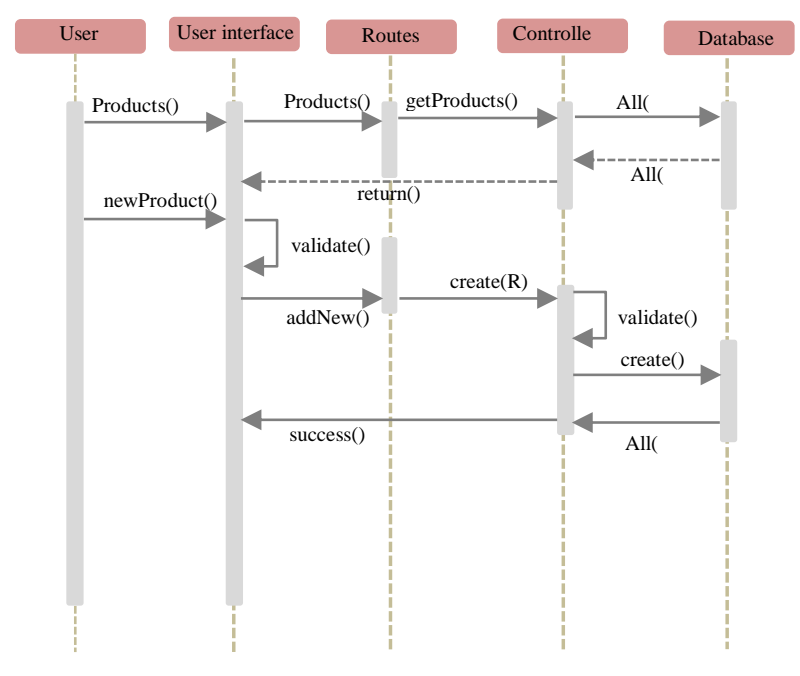

Figure 6 New spare part sequence diagram Source: Own Work

Design and coding: Derived from the previous phase, the functional requirements for the development of the prototype were obtained using the use cases tool, where the users participating in it were clearly identified, at the same time the CRC cards were made, which allowed listing the specific actions, so that, in this way, the coding would be developed efficiently. Figure 7 shows an example of the use case to search for a spare part, it should be noted that in a similar way all the necessary use cases were elaborated to be able to carry out the coding using the laravel framework. Table 4 illustrates the structure of a CRC card, which was used to describe in detail the specific actions in the web application. In figure 8 a code fragment is exemplified, as a result of the design.

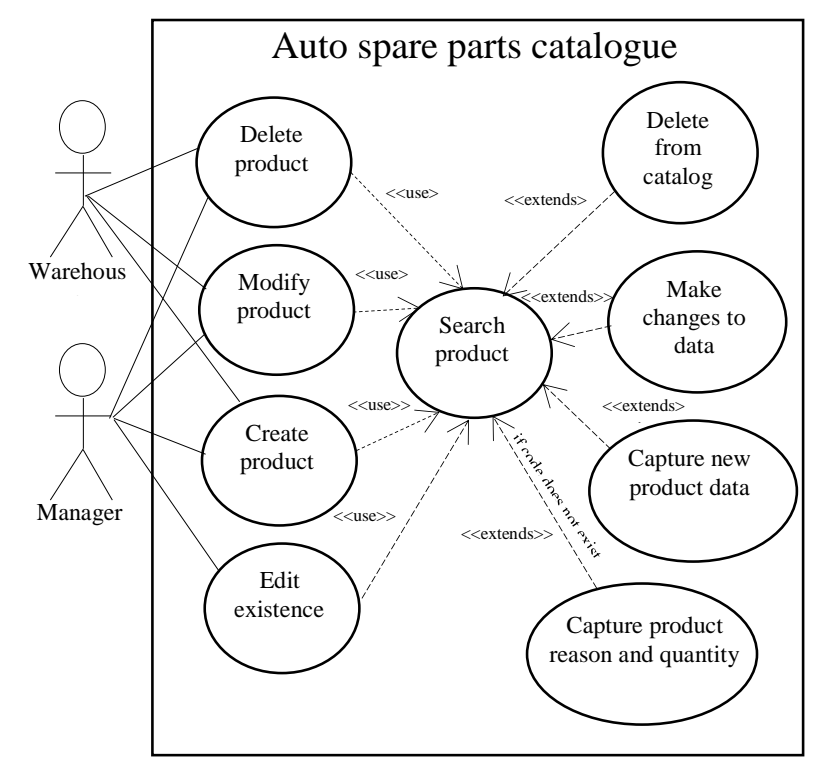

Figure 7 Part Search Use Case Diagram Source: Own Work

\begin{tabular}{|l|l|}
\hline \multicolumn{2}{|c|}{ CRC CARD } \\
\hline Number: & Stage: \\
\hline CRC Name: \\
\hline Responsibilities & Cooperations \\
\hline
\end{tabular}

Table 4 CRC card structure Source: Rajlich (2016)

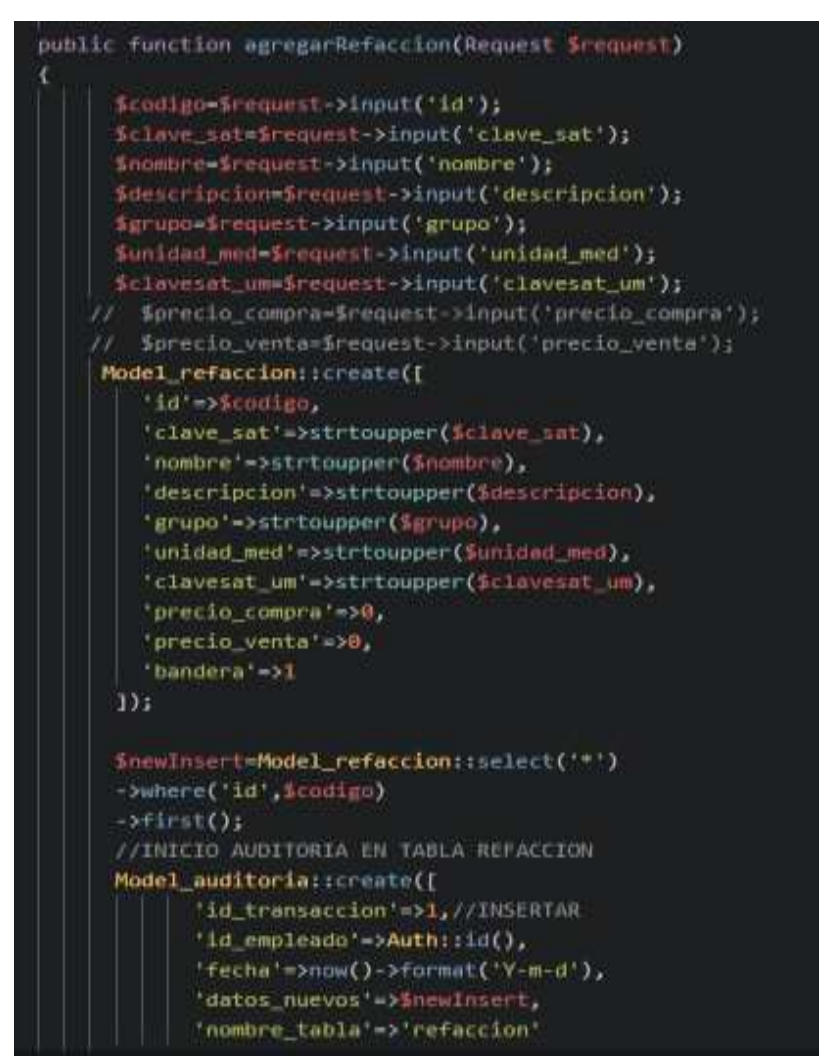

Figure 8 Code example to add part Source: Own Work

Tests: In this phase, the unit and acceptance tests related to the inventory were carried out, considering all possible scenarios according to the business rules of "Refaccionaria R".

Desployment: At this stage, once the user agreed with the functions of this iteration, the inventory module was completed and operational.

\section{Iteration 2. Purchases, orders and cash sales.}

Planning: Taking Table 3 as a reference, the user stories indicated for the second iteration were developed; these have a medium value and medium ease, thus solving the process of purchases, orders and cash sales.

Analysis: Using the sequence diagrams, the requirements and direct actors in the process mentioned in the planning stage were obtained, as an example, the sequence diagram corresponding to the credit sales process is shown in Figure 9.

MORALES-HERNÁNDEZ, Maricela, MORALES-JIMÉNEZ, Itzel, OSORIO-HERNÁNDEZ, Luis Eduardo and DIAZ-SARMIENTO, Bibiana. Prototype of a web and mobile application for inventory management of a parts store using QR code. Journal of Computational Systems and ICTs. 2021 


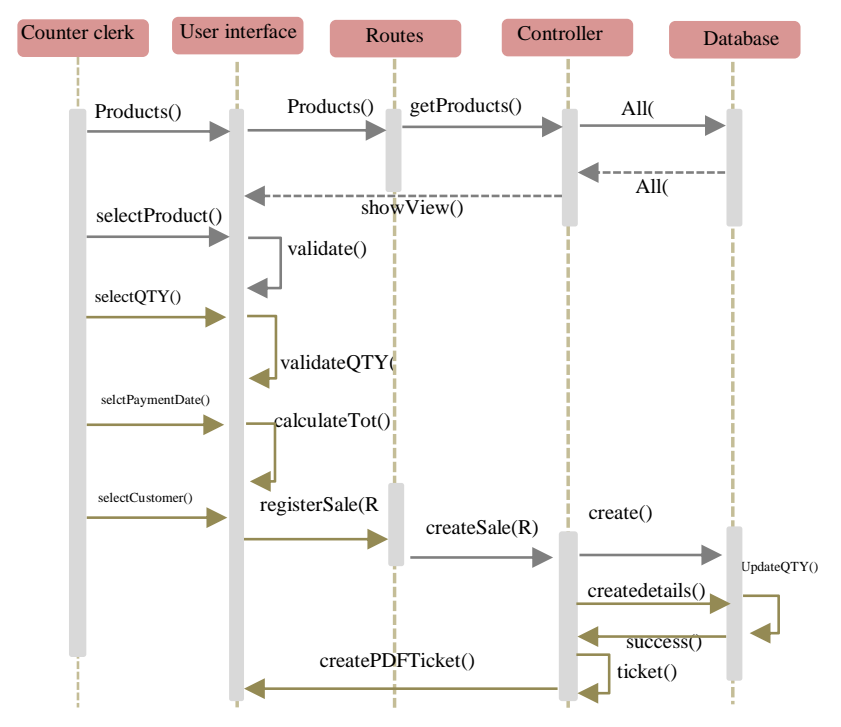

Figure 9. Credit sales sequence diagram Source: Own Work

Design and coding: In this stage, the actions that each user performs according to the aforementioned process were identified, translating them into functional requirements. Tools such as CRC cards and use case diagrams were applied in a similar way to the first iteration. The resulting product in this phase is the coding of the functionalities corresponding to the iteration.

Figure 10 exemplifies one of the use case diagrams carried out in this stage, which corresponds to the use case of credit sales.

On the other hand, figure 11 shows a fragment of the coding that was developed to store a credit sale.

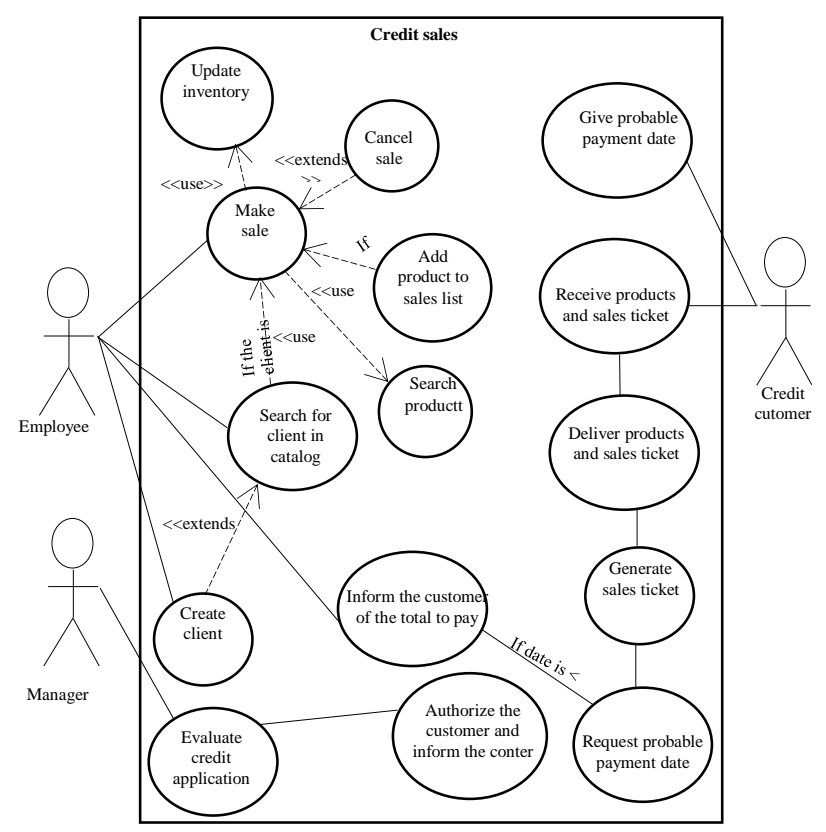

Figure 10 Credit Sales Use Case Diagram

Source: own work

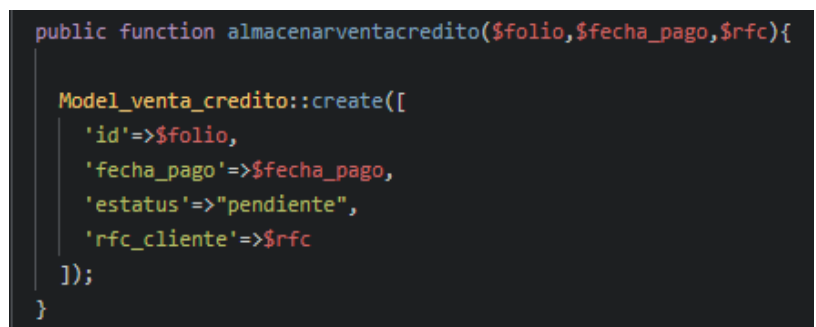

Figure 11 Example of code to solve credit sale storage Source: Own Work

Tests: To start the approval process and completion of iteration three, the unit and acceptance tests were carried out, taking into account the different scenarios described by "Refaccionaria R".

Deployment: Once the relevant tests were applied in the previous phase of the second iteration, the user approved the functionalities corresponding to the purchasing, ordering and cash sales process.

\section{Iteration 3. Returns, vouchers and reports}

Planning: The user stories detailed in Table 3 that correspond to the process of returns, vouchers and reports were developed, also considering the reports obtained from the mobile application when establishing a request for information to the web application. Some examples of this type of report are items in inventory with minimum stock, payment to suppliers, among others. On the other hand, the use of QR codes is taken into account to locate products within the warehouse, using the mobile application. With the above, a functionality is added to the inventory process.

Analysis: Considering the tools already mentioned in this stage in previous iterations, the functional requirements that were obtained to communicate the data between the web application and the mobile application, as well as the identification of requirements for the generation of reports, vouchers and returns.

As an example, Figure 12 shows return sequence diagram, it starts when the employee enters the ticket, the sale interface sends the request to consult the sale through the date and its folio. The routes API sends the query to the controller so that it converts it to the database language. The database returns the query, the controller checks if the return is made at times established by the company, and sends a json file to the web application.

MORALES-HERNÁNDEZ, Maricela, MORALES-JIMÉNEZ, Itzel, OSORIO-HERNÁNDEZ, Luis Eduardo and DIAZ-SARMIENTO, Bibiana. Prototype of a web and mobile application for inventory management of a parts store using QR code. Journal of Computational Systems and ICTs. 2021 
The user selects the part (s) to be returned, the interface makes the request for the return to be registered in the database and the information in the database is updated, and finally, a voucher is generated for the customer.

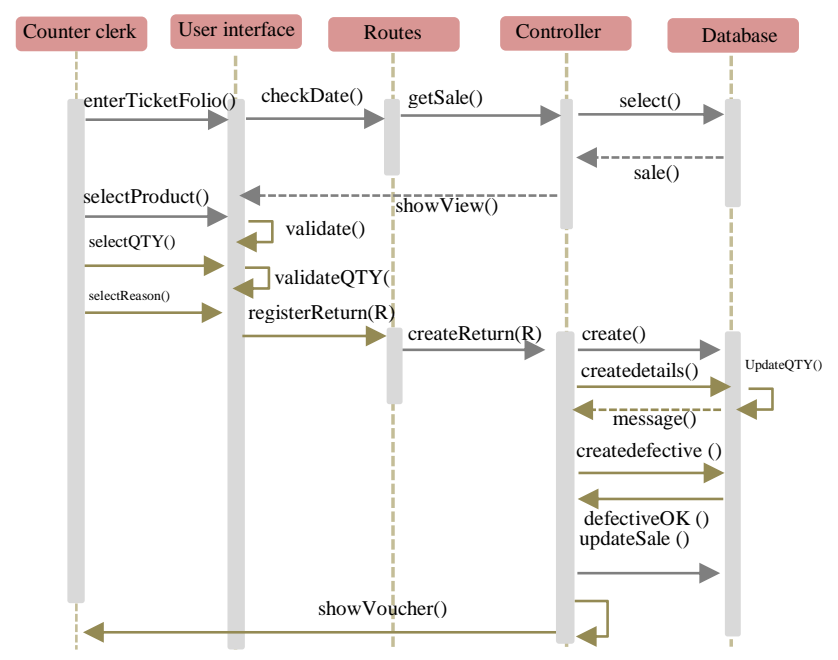

Figure 12 Return sequence diagram Source: Own Work

Figure 13 illustrates the sequence of actions between the mobile application and the web to manage the order list from the mobile application. It starts with a request that can be from the manager or the manager of the warehouse, the application receives the request and sends it to the API routes for analysis, and with the controller, the query is generated on the database. Next, the result of the query is sent to the controller in a json format, it passes it to the routes API, which performs the conversion of the json file to java so that the mobile application displays it in its interface and can be interpreted by the user.

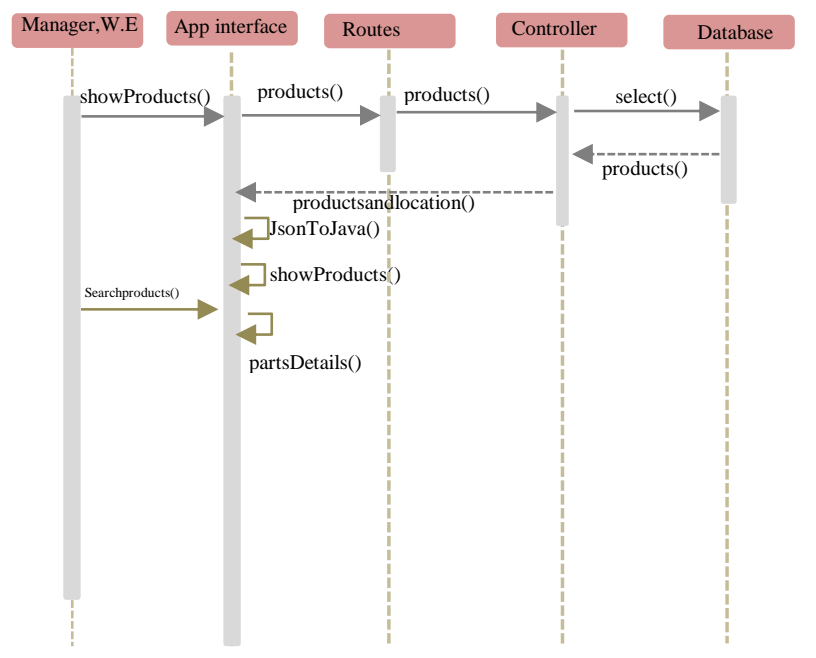

Figure 13 Sequence diagram to manage the tentative list of an order from the mobile app Source: Own Work
Design and coding: This stage defines the correct functioning of the communication between both mobile and web applications, so a diagram was used that specifies the flow that the data communication follows, as highlighted in figure 14. The architecture of the application is client / server, through requests that are interpreted by the server, the requested information is sent to the mobile device through the application. In the server side, it has an API REST, which extract data from database and send response to client. While, client side send a data request through pc terminal or smart phone.

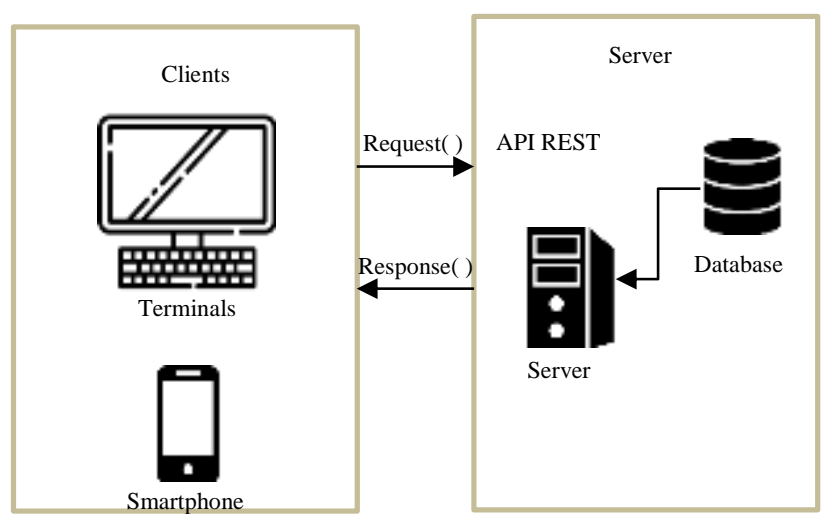

Figure 14 Communication between web and mobile applications

Source: Own Work

In figure 15 you can see a code fragment, which generates a file in PDF format to present a report of the orders that have been made in a specified period of dates.

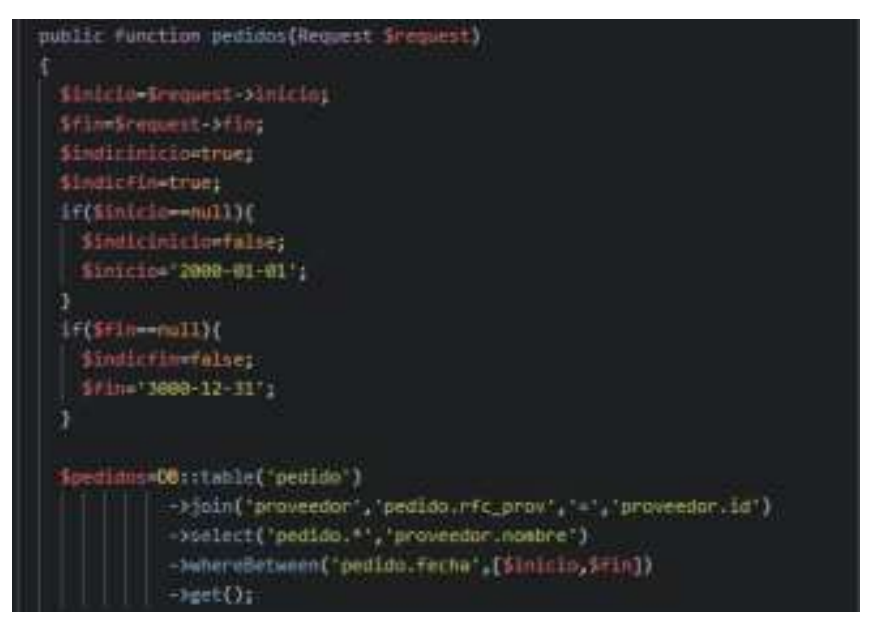

Figure 15 Code fragment to generate order report in PDF format

Source: Own Work

Tests: Unit and acceptance tests were carried out on both applications, web and mobile, verifying the effective communication between them, as well as the visualization of reports in pdf files and the correct operation of QR codes.

MORALES-HERNÁNDEZ, Maricela, MORALES-JIMÉNEZ, Itzel, OSORIO-HERNÁNDEZ, Luis Eduardo and DIAZ-SARMIENTO, Bibiana. Prototype of a web and mobile application for inventory management of a parts store using QR code. Journal of Computational Systems and ICTs. 2021 
Deployment: The user approves the functionalities by verifying that the generated files do not show an error, in the same way with the QR codes it is verified that the search is carried out in an efficient way, therefore, iteration 3 was approved in its entirety, concluding with this way the applications.

\section{Results}

Once the three iterations proposed in the development of the prototype were completed, it was obtained:

1. A web application

2. A mobile application linked to the web application

The different types of user identified in the prototype are:
a. Manager
b. Sale employee
c. Warehouse employee
d. Manager of web and mobile applications

\section{Web Application}

Any of the defined users must authenticate in the application to have access to it. Figure 16 shows the authentication interface; user must have a username and password registered previously to $\log$ in web application.

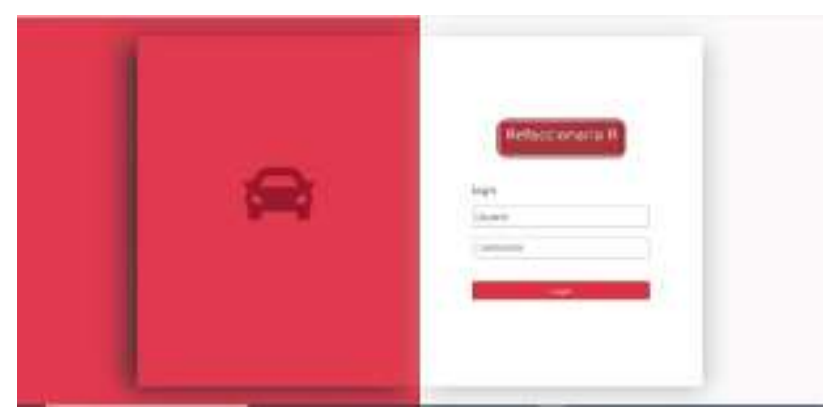

Figure 16 Authentication interface Source: Own Work

Once the user has entered the application, the interfaces are the same, the only thing that changes is that some functionalities are available or not, according to the permissions that "Refaccionaria R" established for each user. The modules of the resulting web application are shown in figure 17 , it should be noted that user have access to these modules, once the user has authenticated.
Figure 18 illustrates the main dashboard for the manager, where some important data for decision-making is quickly displayed, such as: sales of the month, purchases of the month, payment to suppliers, notifications, among others; in addition to showing a graph that reports the accumulated sales of the current year.

Interface for cash sales registration is shown in figure 19, as can be seen on the left side of the interface, the code of the parts that are being sold to the customer is captured and the details of the sale are shown on the right side, as well as the total of it.

Figure 20 illustrates the interface to generate the credit sales report, you have the option of selecting a period for the report, as well as obtaining a report in PDF format. Figure 21 shows an example of a cash sales report, the content of the report has been configured and it can be downloaded in PDF format. This format is portable on different storage media.

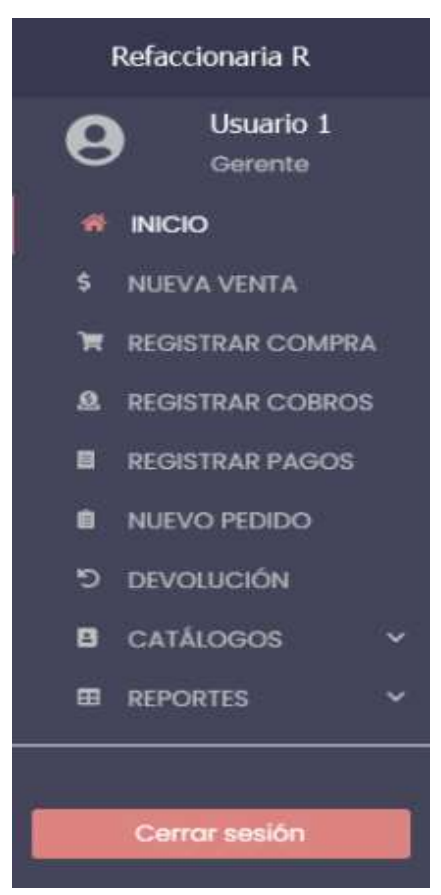

Figure 17 Main menu for the manager Source: Own Work

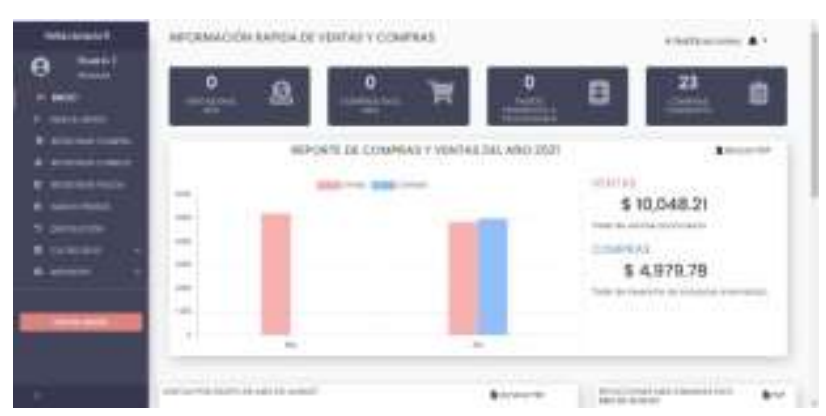

Figure 18 Main dashboard for the manager Source: Own Work

MORALES-HERNÁNDEZ, Maricela, MORALES-JIMÉNEZ, Itzel, OSORIO-HERNÁNDEZ, Luis Eduardo and DIAZ-SARMIENTO, Bibiana. Prototype of a web and mobile application for inventory management of a parts store using QR code. Journal of Computational Systems and ICTs. 2021 


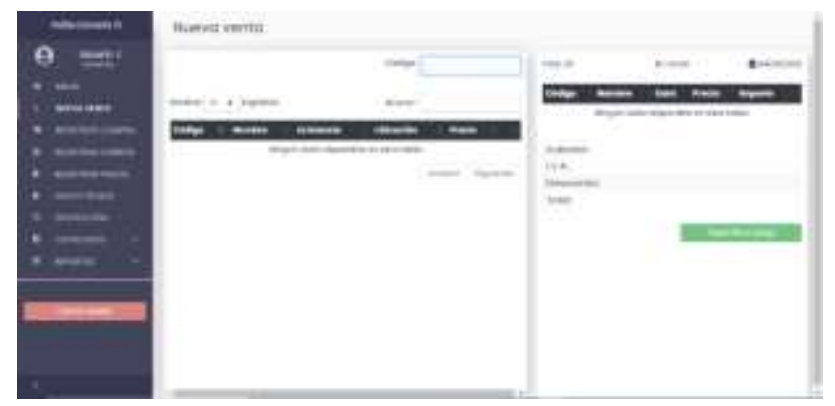

Figure 19 Interface for cash sales registration Source: Own Work

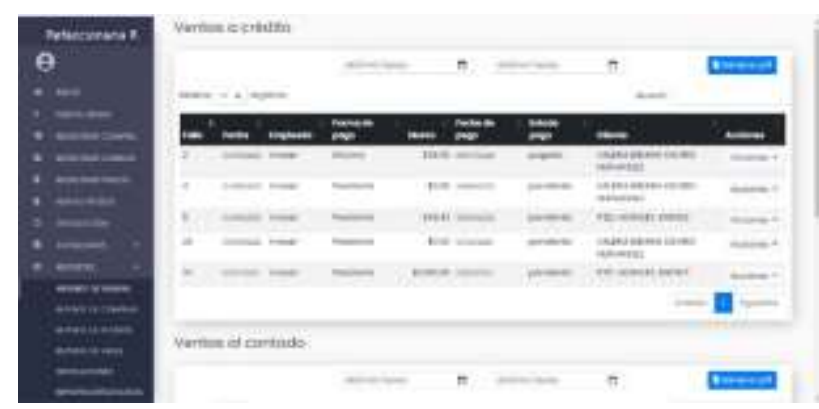

Figure 20 Interface to generate the credit sales report Source: Own Work

\section{Refaccionaria R}

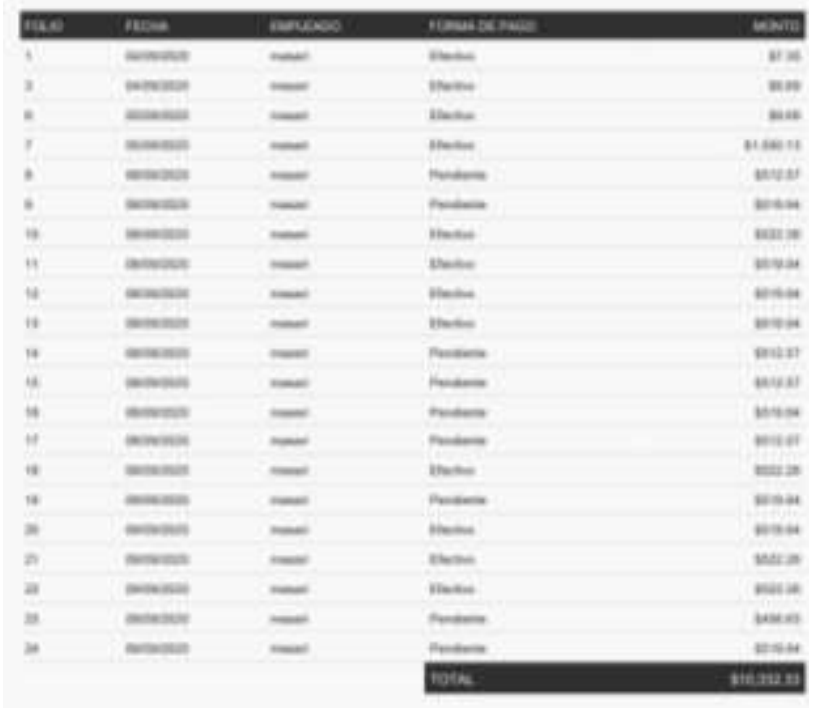

Figure 21 Example of a cash sales report Source: Own Work

In the web application there is a function to generate the $\mathrm{QR}$ code, which identifies in which shelf a group of products is stored, defined by a categorization previously established by "Refaccionaria R".

The QR code presented in figure 22 is read by the mobile application, which will show the corresponding shelf within the warehouse where a specific product can be located.

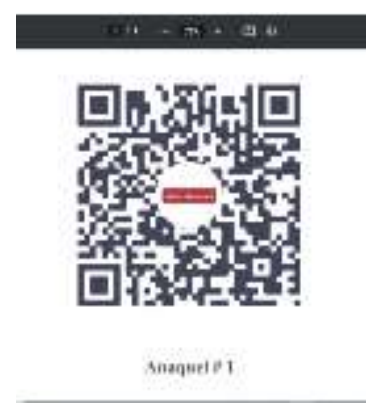

Figure $22 \mathrm{QR}$ code generated by the web application Source: own work

\section{Mobile Application}

For the mobile application there is also a user authentication interface, this is shown in figure 23. To enter the mobile app it is required that the user has been previously registered to have the username and password requested by the Interface as you can see in figure 23. Once the user has been authenticated, the menu available in the application is shown, as can be seen in figure 24, it requires connection functions between the mobile application and the web application. The available functions are parts tentative list, automotive spare parts to query, orders, and, notifications.

For the quick search of products in the warehouse, the QR code generated by the web application can be digitized (see figure 23), and when it is read the app shows in which shelf that product is physically stored, which facilitates management of inventory and save time on customer service at the shop. The function of recognizing the $\mathrm{QR}$ code by the mobile app is illustrated in figure 25, when Web App generates QR code, show it on screen, with mobile camera, mobile app reads the code, and interprets it.

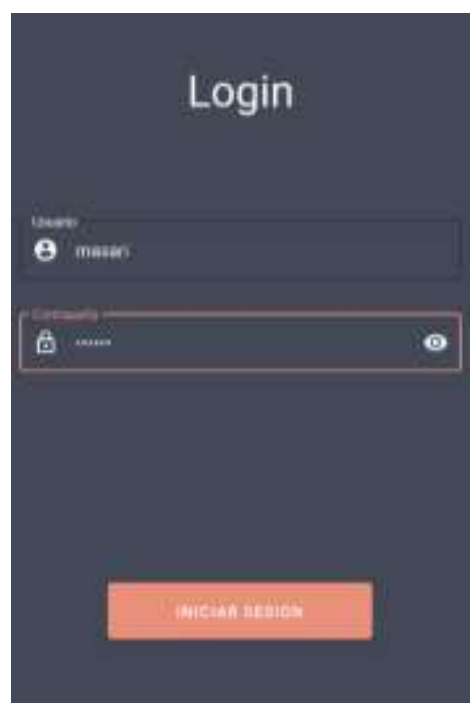

Figure 23 Login interface for the mobile app Source: Own Work

MORALES-HERNÁNDEZ, Maricela, MORALES-JIMÉNEZ, Itzel, OSORIO-HERNÁNDEZ, Luis Eduardo and DIAZ-SARMIENTO, Bibiana. Prototype of a web and mobile application for inventory management of a parts store using QR code. Journal of Computational Systems and ICTs. 2021 


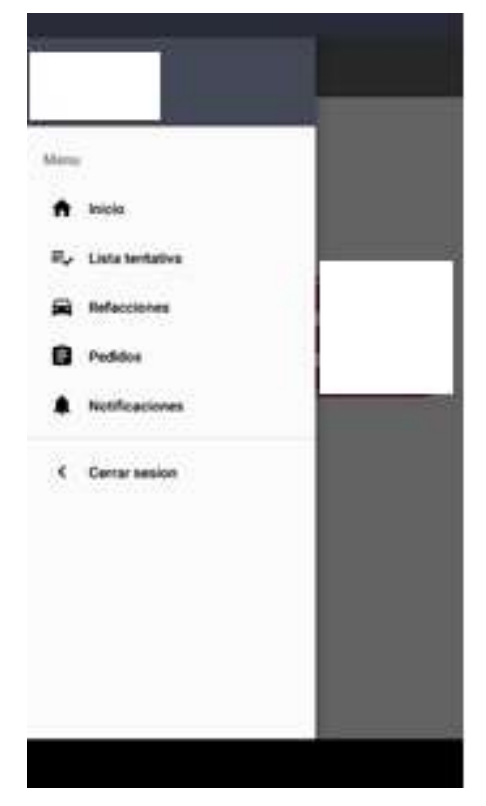

Figure 24 Mobile App main menu Source: Own Work

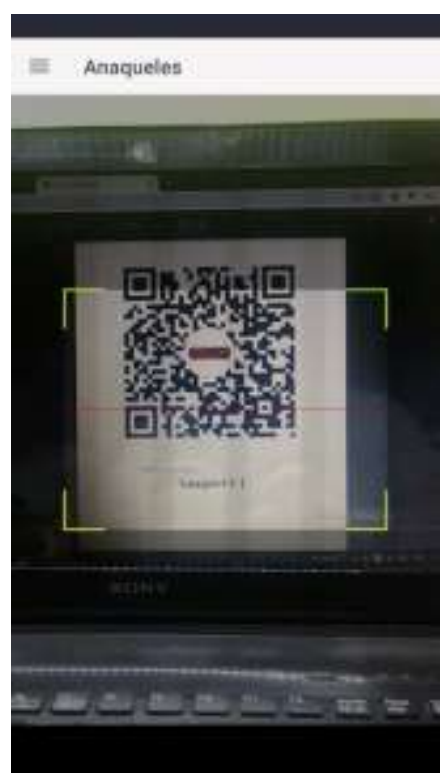

Figure 25 Reading the $\mathrm{QR}$ code by the mobile application Source: Own Work

Once the mobile app reads the QR code, the product information is displayed as shown in figure 26. Here you can see that the description of the set of products grouped on the shelf is detailed, as well as their identification code and the quantity in stock. On this example it was used the key word "white"; the word identify the color of the shelf.

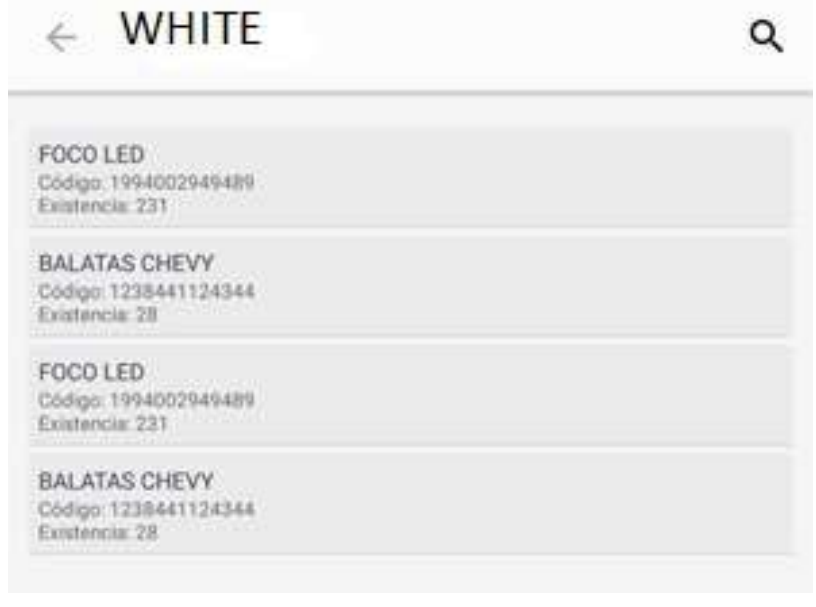

Figure 26 Result report of reading the $\mathrm{QR}$ code from the mobile app

Source: Own Work

This first web and mobile prototype permited that the work team realize that microenterprises requires solutions to theirs problematics, and, that microenterprises is a market segment that cannot spend a lot of money on software solutions; nevertheless, these solutions contribute that they can compete and remain on the market. For this reason, is important developing| low costs solutions for them.

\section{Future work}

The prototype that was proposed to solve the management problems of the "Refaccionaria R" warehouse was concluded according to expectations; however, once the deployment was made with the microenterprise, new needs appeared, mainly to build other modules such as clients, collection, personnel, among others, to achieve a comprehensive system that includes all the activities of "Refaccionaria R".

These proposals would have to be carried out in a second phase of development, first establishing the most urgent needs from the point of view of the auto parts store.

In other hand, the web and mobile application can be registered to protect copyright, so, work team will get the requirements to do. Of course, it is important to considering the point of view of "Refaccionaria R", since the prototype was developed for the microenterprise. 


\section{Acknowledgments}

We are grateful for the support provided by the National Technological Institute of Mexico, which through the Technological Institute of Oaxaca have provided the facilities and spaces for the development of research; as well as the support for the elaboration of this article.

The collaboration and dedication of the authors of the article, professors and students who participate in the research are also widely appreciated. Hoping that, for all of them, the divulgation of the work carried out will result in their professional development.

Finally, we are grateful for the collaboration of "Refaccionaria R", which at the request of confidentiality does not reveal the real name, but without their contributions and points of view it would not have been possible to determine the functional requirements of the prototype obtained.

\section{Conclusions}

The objective of developing a web and mobile application for managing the inventory of a small business model, represented by "Refaccionaria R", it was fulfilled, since a functional prototype was obtained that has been subjected to different tests by users. There were some setbacks in the development process, mainly due to the confinement of the global Covid-19 pandemic. The foregoing had a significant impact on the schedule of activities in the project; however, following the "home office" work model, the prototype could been reorganized and finished successfully.

It is important to point out that the solutions that can be offered to small companies are developed minimizing as much as possible the costs in the development tools, as well as the labor of the developer team, so it was decided to work with open source tools such the laravel framework. Under this idea, microenterprises can obtain technologies for their daily work without spending large amounts of money.

This work represents an option for small companies that continue to work under manual schemes for the management of their inventories, and it gives them an opportunity to reorient the functions of their personnel, organizing and distributing the work according to the company aims.

ISSN-2444-5002

ECORFAN® All rights reserved
The web and mobile application facilitate inventory management, which in some cases represents a persistent problem in companies that sell products and that need to maintain a warehouse of them in order to effectively supply their customers. Keeping greater organization and control over their inventories allows them to save both material and human resources in the development of their most important activities, and redirect the work of their employees to actions that result in greater productivity for the company.

It is important to emphasize that a prototype will always have opportunities to improve its functions and this will be achieved to the extent that it is tested in a real work environment, under the normal loads that companies experience.

Educational institutions that train professionals in the field of computing, such as the Technological Institute of Oaxaca, are able, through these projects, to establish a link with their environment by providing technical advice and functional products to companies, which are in the institution's area of influence.

\section{References}

Android. (2021). Introducción a Android Studio. Recuperado el día 15 de julio de 2021 de https://developer.android.com/studio/intro

Busines Insider México. (03 de mayo de 2021). What is a QR code? A guide to the barcode's basics, why you're seeing it everywhere, and how to scan one. https://businessinsider.mx/what-is-a-qrcode/? $\mathrm{r}=\mathrm{US} \& \mathrm{IR}=\mathrm{T}$

Calero, C., Moraga, M.A., Piattini, M.G. (2010). Calidad del producto y proceso software. España: RA-MA Editorial.

David, J. (18 de abril de 2021). Top 7 Android App Development Fundamentals for Beginners. Sysbunny. https://www.sysbunny.com/blog/top7-android-app-development-fundamentals-forbeginners/

Ferrer, J. (2015). Aplicaciones Web. España: RA-MA, S.A. Editorialo y Publicaciones. 
IntelliJ IDEA. (2021). IntelliJ IDEA overview. IntelliJ IDEA. https://www.jetbrains.com/help/idea/discoverintellij-idea.html.

Laínez, J.R. (2015). Desarrollo de Software Ágil: Extremme Programming y Scrum. España: ITcampus Academy.

Laravel. (2021). Laravel Philosophy. https://laravel.com/docs/4.2/introduction

Molinero, J.M. (2018). UF2218 - Desarrollo de un $C M S$. España: Editorial Elearning, S.L.

Rajlich, V. (2016). Software Engineering: The Current Practice. US: CRC Press.

Redhat (2021). El concepto de desarrollo de aplicaciones móviles para empresas. https://www.redhat.com/es/topics/mobile

Velasco, J. (2014), Gestión de la logística en la empresa. Planificación de la cadena de suministros. España: Ediciones Pirámide. 